RESEARCH PAPER

\title{
The St-Louis du Parc Heart Health Project: a critical analysis of the reverse effects on smoking
}

\author{
L Renaud, J O'Loughlin, V Déry
}

Tobacco Control 2003;12:302-309

See end of article for authors' affiliations

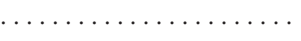

Correspondence to: Lise Renaud, 1301

Sherbrooke Street East,

Montreal, Quebec H2L

1M3, Canada:

Irenaud@santepub-mtl.qc.ca

Received 23 July 2002

Accepted 28 March 2003

\begin{abstract}
Objectives: Although some school based smoking prevention programmes have shown positive impacts, others have had only short term effects, no effects, and in some cases reverse effects. The St-Louis du Parc Heart Health Project was a five year heart health promotion programme targeting children in eight elementary schools aged 9-12 years in disadvantaged multiethnic neighbourhoods in Montreal. In a controlled, longitudinal evaluation, the programme produced reverse effects on smoking-children exposed to the programme were more likely to initiate and to continue smoking than control children. This article explores hypotheses to explain the reverse effects.

Design: Following work by an in-house committee, a consensus workshop with international experts was conducted to develop hypotheses to explain the reverse effects. This was complemented by an analysis of the programme's concordance with the standard guidelines on the school based prevention of tobacco use, and discussions with experts at the Centers for Disease Control and Prevention.

Results: The programme respected most standard guidelines for smoking prevention programmes with respect to content and mode of delivery. Hypotheses to explain the reverse effects include: an unfavourable environment characterised by strong pro-smoking models and resistance to environmental interventions; heightened sensitivity to smoking among children most exposed to the programme; defence mechanisms among children stimulated by cognitive dissonance or anxiety; unanticipated effects associated with the health educator who delivered the programme; inadequate attention in programme development to the diverse cultural origins of the population targeted; and intervention content inappropriately targeted to children's stages of cognitive development.

Conclusion: Elementary school based interventions should aim to develop a clear and coherent social norm about the non-use of tobacco, as a precursor to or in close conjunction with having children as their primary target. Programme design should take key student characteristics into consideration and ensure that the modes of communication are adapted to the targeted group's characteristics. Neighbourhood level interventions should be orchestrated to complement regional, provincial, and national programmes.
\end{abstract}

D espite many successes in school based smoking prevention programmes, ${ }^{1-5}$ several studies have suggested that such programmes are sometimes less effective than desired. Short term positive impacts tend to dissipate over time, ${ }^{6-9}$ while several comprehensive prevention projects have failed to show positive effects. ${ }^{19-11}$ Of particular note is the recent school based smoking prevention trial described by Hutchison et al. ${ }^{9}$ Designed to provide the definitive test of short and long term impacts on smoking outcomes, this evaluation raised serious concerns that current approaches to school based smoking prevention are ineffective, although generalising the findings to every smoking prevention programme based on social influence might not be warranted. ${ }^{12}$

Even more disturbing, several prevention programmes report negative or reverse effects, increasing smoking among exposed children. The Life Education Program in Australia ${ }^{13}$ provided a drug use prevention curriculum to sixth graders. Although the findings were strongly contested by programme promoters, ${ }^{14}{ }^{15}$ recent smoking among $43 \%$ of girls and 35\% of boys was attributed to participation in the programme. ${ }^{13}$ Similarly, evaluation of an anti-smoking curriculum called Project Alert (California and Oregon) showed that in schools where the anti-smoking curriculum was delivered to seventh and eighth graders by an adult health educator in conjunction with teen leaders, continued smoking among baseline smokers was significantly increased compared to control schools. ${ }^{16}{ }^{17}$ Gilchrist et $a l^{17}$ found that, in an evaluation of a self control intervention, smoking rates in the intervention group-which received in-class sessions on factual infor- mation about smoking and health-were higher than in the control group. Finally, in an evaluation of two school based smoking education programmes in Wales, Nutbeam ${ }^{18}$ reported that non-smoking youth exposed to the programmes were less likely to remain never smokers compared to non-smokers not exposed to the programme.

The St-Louis du Parc Heart Health Project targeted smoking among youth as part of a comprehensive, multifactorial cardiovascular disease prevention programme, which included school based interventions combined with political action, community organisation, and family involvement. This five year programme in a low income, multiethnic neighbourhood in Montreal (Quebec, Canada) had positive effects on physical activity, but produced unambiguously negative effects on smoking in children aged 9-12 years. Both initiation of smoking and continued smoking were higher among intervention students than students in comparison schools, after exposure to the programme. ${ }^{19} 20$

Once design problems and analytical errors were ruled out, an in-house working committee was created, consisting of professionals with complementary expertise in public health, medicine, epidemiology, psychology, education, and sociology. A literature review established that this was not an isolated finding, and that reverse effects were frequent enough to warrant investigation of possible underlying mechanisms, rather than ignoring them or attributing them to chance. In April 2000, a workshop was held with national and international experts with diverse tobacco related expertise (researchers, programme developers, and members of the standard 
Table 1 Comparison of outcomes by treatment in the condition in the longitudinal cohort sample surveys : Montreal, Quebec, 1994-97

\begin{tabular}{|c|c|c|c|c|c|c|}
\hline \multirow[b]{2}{*}{ Outcome* } & \multicolumn{2}{|c|}{ Intervention } & \multicolumn{2}{|c|}{ Comparisonף } & \multicolumn{2}{|c|}{$\begin{array}{l}\text { Intervention relative to comparison } \\
\text { condition }\end{array}$} \\
\hline & Number & $\%$ & Number & $\%$ & OR $(95 \% \mathrm{Cl}) \dagger$ & $\mathrm{p}$ Value \\
\hline \multicolumn{7}{|l|}{ One year follow up } \\
\hline Initiated smoking $\ddagger$ & $79 / 339$ & 23.3 & $172 / 1233$ & 13.9 & 1.87 (1.34 to 2.61$)$ & 0.0002 \\
\hline $\begin{array}{l}\text { Continued smoking§ } \\
\text { Least intense intervention }\end{array}$ & $71 / 148$ & 48.0 & $81 / 273$ & 29.7 & 2.72 (1.71 to 4.33 ) & 0.0001 \\
\hline Initiated smoking $\ddagger$ & $25 / 196$ & 12.8 & $172 / 1233$ & 13.9 & $0.73(0.44$ to 1.25$)$ & 0.2577 \\
\hline \multicolumn{7}{|l|}{ Total } \\
\hline Initiated smoking $\ddagger$ & $104 / 535$ & 19.4 & $172 / 1233$ & 13.9 & $1.44(1.06$ to 1.95$)$ & 0.0188 \\
\hline Continued smoking§ & $95 / 199$ & 47.7 & $81 / 273$ & 29.7 & 2.59 (1.69 to 3.97$)$ & 0.0001 \\
\hline \multicolumn{7}{|l|}{ Two year follow up } \\
\hline Initiated smoking $\ddagger$ & $39 / 97$ & 40.2 & $60 / 328$ & 18.3 & 2.88 (1.65 to 5.01$)$ & 0.0002 \\
\hline \multicolumn{7}{|l|}{ Least intense } \\
\hline Initiated smoking $\ddagger$ & $9 / 61$ & 14.8 & $60 / 328$ & 18.3 & $0.58(0.25$ to 1.35$)$ & 0.2050 \\
\hline \multicolumn{6}{|l|}{ Total } & 0.1541 \\
\hline Initiated smoking $\ddagger$ & $48 / 158$ & 30.4 & $60 / 328$ & 18.3 & 1.95 (1.17 to 3.23$)$ & 0.0100 \\
\hline Continued smoking§ & $31 / 58$ & 53.4 & $17 / 57$ & 29.8 & 3.03 (1.26 to 7.27$)$ & 0.0130 \\
\hline \multicolumn{7}{|c|}{$\begin{array}{l}\text { *Baseline and follow up values for each outcome are unadjusted prevalences or means. } \\
\text { tOdds ratios (OR) and } 95 \% \text { confidence intervals }(95 \% \mathrm{CI}) \text { for treatment condition (intervention relative to comparison) obtained from GEE in the one year } \\
\text { follow up analysis, and from multiple logistic regression analyses in two year follow up analysis, controlling where appropriate, for baseline level of the } \\
\text { dependent variable, age, grade, sex, family status (that is, single parent, two parent), mother's employment status, father's employment status, subject born } \\
\text { in or outside Canada, family ethnic origin, cohort ( } 1994-96) \text {, mother smokes, father smokes, sibling(s) smoke, friends smoke. } \\
\text { †Among subjects who were never smokers at time } 1(n=1821 \text { in the one year follow up; } n=502 \text { in the two year follow up). } \\
\S \text { Among subjects who had ever smoked at time } 1 \text { ( } n=498 \text { in the one year follow up; } n=120 \text { in the two year follow up). } \\
\text { ๆComparison schools are the same across all levels of intervention. }\end{array}$} \\
\hline
\end{tabular}

guidelines development teams from the USA and Canada) to develop hypotheses to explain the unexpected reverse effects, to critically re-examine smoking prevention strategies targeting elementary school children, and to propose alternative avenues for intervention. Finally, in November 2000, the in-house team met with experts from the Centers for Disease Control, Division of Smoking Reduction, to discuss the extent to which the St-Louis du Parc Heart Health Project was consistent with standard guidelines for school based prevention of tobacco use, and to provide additional insights into the results. The findings from these three sets of consultations were integrated gradually in an iterative process which synthesised the information to generate hypotheses. The consensus around these hypotheses is presented in this article.

\section{DESCRIPTION OF THE PROGRAMME}

The St-Louis du Parc Heart Health Project was implemented from 1992 to 1997, among children aged 9-12 years in an inner city neighbourhood served by the St-Louis du Parc Local Community Health and Social Service Centre (CLSC) in Montreal, Canada. The population of this low income territory is multiethnic. ${ }^{21}$ The St-Louis du Parc Heart Health Project was based on the hypothesis that a comprehensive programme of interventions targeting both children and significant adults (family, youth workers, teachers, nurses), for multiple risk factors (sedentary behaviour, obesity, and smoking) in multiple sites (schools, community organisations, recreation centres, and homes) and using diverse strategies outlined in the Ottawa Charter for Health Promotion ${ }^{22}{ }^{23}$ (healthy public policies, community development, supportive environments, and personal skills development) would have an impact on children's cardiovascular risk factor profiles (physical activity, non-smoking, and diet). The programme was implemented in eight elementary schools, four recreation organisations, four cultural organisations, and the CLSC..$^{22} 25$

\section{Smoking related interventions}

The programme comprised 25 interventions that targeted children, significant adults, and their environments. ${ }^{24}$ Three interventions focused specifically on smoking: a school based anti-smoking curriculum, an extracurricular programme, and enforcement of a law prohibiting the sale of tobacco to minors. The analysis reported here was restricted to the school based curriculum because it was the only intervention to which all subjects were exposed.

Of 20 hours devoted annually to the heart health school curriculum, 5-8 hours were dedicated to smoking prevention. The smoking prevention curriculum was developed in 1991 based on the results of published meta-analyses on smoking prevention in schools, ${ }^{26}$ the 1991 recommendations for youth tobacco prevention programming of the National Cancer Institute, ${ }^{27}$ and an examination of existing school based prevention programmes (that is, the Waterloo ${ }^{28} 29$ and Know Your Body programmes ${ }^{30}$ ). Based on social learning theory and geared to age specific stages of cognitive development, the content of the programme aimed to: provide information about the effects of tobacco on health; develop non-smoking attitudes; and consolidate or develop skills in peer pressure resistance and decision making. It also aimed to stimulate schools to adopt smoke-free policies. A health educator delivered the programme during the first year in grades 4, 5, and 6. Subsequently teachers were asked to administer the curriculum, although some continued to ask that the health educator teach it. The health educator was therefore present in participating schools for the full five years of the project.

\section{EVALUATION METHODS}

The impact of the programme was assessed in a quasiexperimental study design in which eight experimental schools were matched to 16 comparison schools on poverty and language indices. Data were collected in a total of 11195 questionnaires. The response proportions in the longitudinal 
Table 2 Examination of the St-Louis du Parc Heart Health Project in terms of the recommendations found in the literature and formulated by experts

\begin{tabular}{|c|c|c|c|}
\hline Elements & Recommendations & St-Louis du Parc project & Comments \\
\hline Content of the curriculum & $\begin{array}{l}\text { LR: A school based intervention should } \\
\text { focus on information, attitudes, and skills } \\
\text { to resist social and behavioural } \\
\text { influences } \\
\mathrm{NCI} \text { : The school based programme } \\
\text { should emphasise social factors, } \\
\text { consequences, and refusal skills } \\
\mathrm{CDC} \text { : The intervention should focus on } \\
\text { the physiologic and social } \\
\text { consequences, social influences, peer } \\
\text { norms regarding tobacco use, and } \\
\text { refusal skills }\end{array}$ & $\begin{array}{l}\text { The curriculum was developed based on } \\
\text { the social learning theory and dealt with } \\
\text { knowledge, attitudes, skills, and } \\
\text { behaviours to adopt regarding } \\
\text { abstinence from tobacco }\end{array}$ & Recommendations respected \\
\hline Incorporation & $\begin{array}{l}\mathrm{NCl} \text { : Incorporated into existing curricula } \\
\mathrm{IM} \text { : Incorporated into drug programmes }\end{array}$ & $\begin{array}{l}\text { The school based intervention was } \\
\text { negotiated with a view to being } \\
\text { incorporated into PSE (personal and } \\
\text { social education) classes. In fact, the } \\
\text { implementation assessments indicate that } \\
\text { it was also incorporated into other } \\
\text { subjects }\end{array}$ & Recommendations respected \\
\hline Intensity of the curriculum & $\begin{array}{l}\mathrm{NCl} \text { : minimum of five sessions/year } \\
\mathrm{LR} \text { : in all, } 10 \text { sessions to observe } \\
\text { sustainable effects }\end{array}$ & $\begin{array}{l}\text { Programme content: } 4 \text { th grade: eight } \\
50 \text { minute sessions on smoking ( } 5 \\
\text { compulsory and } 3 \text { optional). } 5 \text { th grade: } \\
\text { five } 50 \text { minute sessions. } 6 \text { th grade: five } \\
50 \text {-minute sessions } \\
\text { Note, however, a variation in the } \\
\text { number of hours by school. The four } \\
\text { schools in which the majority of the } \\
\text { sessions were given reported more } \\
\text { negative effects }\end{array}$ & Two recommendations respected \\
\hline $\begin{array}{l}\text { Curriculum booster } \\
\text { sessions or spread out } \\
\text { over more than one school } \\
\text { year }\end{array}$ & $\begin{array}{l}\text { LR: } 5 \text { booster sessions LR: At least three } \\
\text { consecutive years }\end{array}$ & $\begin{array}{l}\text { Programme offered to the same students } \\
\text { over three consecutive years }\end{array}$ & Both recommendations respected \\
\hline $\begin{array}{l}\text { Curriculum administration } \\
\text { time }\end{array}$ & $\begin{array}{l}\mathrm{NCl} \text { : Initiated during the transition from } \\
\text { elementary school to high school (6th } \\
\text { grade and secondary 1) } \\
\text { CDC: From kindergarten to the end of } \\
\text { high school }\end{array}$ & $\begin{array}{l}\text { Programme offered from } 4 \text { th to } 6 \text { th } \\
\text { grade, therefore initiated at the } \\
\text { beginning of the transition }\end{array}$ & $\begin{array}{l}\text { Recommendation respected. An } \\
\text { evaluation by the former Montreal } \\
\text { General Hospital community health } \\
\text { department of the impact of smoking } \\
\text { related programmes available to } \\
\text { kindergarten and } 1 \text { st grade students } \\
\text { indicated that they had very little effect }\end{array}$ \\
\hline $\begin{array}{l}\text { Teacher rather than an } \\
\text { outside health professional } \\
\text { delivering the curriculum }\end{array}$ & $\begin{array}{l}\text { The literature makes two comments on } \\
\text { this subject: Direct interventions with } \\
\text { youth without going through teacher } \\
\text { training, therefore with a health } \\
\text { professional. In traditional health } \\
\text { education type interventions, teachers } \\
\text { generated more positive results than an } \\
\text { outside health professional }\end{array}$ & $\begin{array}{l}\text { A health professional offered the } \\
\text { programme directly to the first cohort. } \\
\text { For the other cohorts, the interventions } \\
\text { were conducted jointly by the teacher } \\
\text { and the health professional }\end{array}$ & $\begin{array}{l}\text { Recommendation respected. Note that } \\
\text { the outside health professional was } \\
\text { present for five years in the same } \\
\text { schools. In this case can we still describe } \\
\text { the person as an outside health } \\
\text { professional? }\end{array}$ \\
\hline Teacher training & $\begin{array}{l}\mathrm{NCl} \text { : Adequate teacher training } \\
\mathrm{CDC} \text { : Programme specific teacher } \\
\text { training }\end{array}$ & $\begin{array}{l}\text { Each year, the teachers were trained on } \\
\text { the whole programme for } 2 \text { days, } \\
\text { including a half day on smoking. In } \\
\text { addition, the health professional was } \\
\text { available on request for additional } \\
\text { supervision }\end{array}$ & $\begin{array}{l}\text { Recommendation respected. What } \\
\text { criteria are used to define adequate } \\
\text { training? These were not explicitly } \\
\text { defined by the } \mathrm{NCl} \text {. Can regular support } \\
\text { by the health professional be considered } \\
\text { a training aid for teachers? The } \\
\text { implementation assessments of Heart } \\
\text { Health St-Louis du Parc suggest that the } \\
\text { teachers learned with the presence of the } \\
\text { health professional }\end{array}$ \\
\hline Intervention by peers & $\begin{array}{l}\text { LR: The student gives information to the } \\
\text { other students. The teacher is a facilitator } \\
\mathrm{NCl} \text { : Students should be involved in the } \\
\text { presentation and delivery of the } \\
\text { programme }\end{array}$ & $\begin{array}{l}\text { The 6th grade students are responsible } \\
\text { for conveying information to the } 4 \text { th and } \\
5 \text { th grade students }\end{array}$ & $\begin{array}{l}\text { Recommendation respected for 6th } \\
\text { grade. Because of the children's age } \\
\text { (see below on cognitive development } \\
\text { and moral judgement), we did not feel } \\
\text { that peer based intervention was } \\
\text { appropriate before the 6th grade }\end{array}$ \\
\hline Cessation course & $\begin{array}{l}\text { CDC: Support cessation efforts among } \\
\text { students and teachers }\end{array}$ & $\begin{array}{l}\text { When required, the health professional } \\
\text { offered assistance to student smokers } \\
\text { who asked for help, on an individual } \\
\text { basis. On occasion, the health } \\
\text { professional suggested the help. At the } \\
\text { beginning of the project, the teachers } \\
\text { clearly indicated that they objected to } \\
\text { the intervention being directed at their } \\
\text { own habits. However, in the last } 18 \\
\text { months, some of the teachers asked us to } \\
\text { organise cessation sessions }\end{array}$ & $\begin{array}{l}\text { Recommendation partially respected } \\
\text { because of the age of the students. We } \\
\text { did not systematically plan cessation }\end{array}$ \\
\hline
\end{tabular}


Table 2 Continued Examination of the St-Louis du Parc Heart Health Project in terms of the recommendations found in the literature and formulated by experts

\begin{tabular}{|c|c|c|c|}
\hline Elements & Recommendations & St-Louis du Parc project & Comments \\
\hline Research & $\begin{array}{l}\text { LR: The implementation assessment } \\
\text { identifies the process explaining the } \\
\text { success or failure of the programme } \\
\text { CDC: Assess the smoking programmes } \\
\text { on a regular basis } \\
\text { IM: Idem and research should be } \\
\text { conducted to identify needs, and } \\
\text { develop and evaluate prevention } \\
\text { programmes among ethnic groups }\end{array}$ & $\begin{array}{l}\text { The school intervention was the subject } \\
\text { of several types of evaluation: } \\
\text { adjustment of the programme for ethnic } \\
\text { communities, implementation } \\
\text { assessment, and impact assessment }\end{array}$ & Recommendations respected \\
\hline \multirow[t]{2}{*}{ Comprehensive approach } & $\begin{array}{l}\text { IM: A comprehensive approach for a } \\
\text { programme includes broader social } \\
\text { networks such as parents, community, } \\
\text { and the media }\end{array}$ & $\begin{array}{l}\text { The school based intervention was part } \\
\text { of an overall Heart Health Program } \\
\text { involving interventions on policies, } \\
\text { parental and teacher involvement, and } \\
\text { the involvement of ethnic groups. } \\
\text { Specifically, no media intervention } \\
\text { designed exclusively for our population } \\
\text { was organised. The Portuguese, } \\
\text { Hispanic, and Chinese communities, } \\
\text { through their own community } \\
\text { organisations, produced media } \\
\text { interventions for the project (radio, TV, } \\
\text { newspapers) }\end{array}$ & Recommendation respected \\
\hline & $\begin{array}{l}\text { CDC: Enforce school policies on tobacco } \\
\text { use and involve parents }\end{array}$ & $\begin{array}{l}\text { However, tobacco was not the central } \\
\text { theme. Parental involvement was } \\
\text { concretised through letters that they } \\
\text { signed but also by their presence at } \\
\text { certain activities. Parental participation } \\
\text { varied from school to school. At first, the } \\
\text { programme ensured the existence of } \\
\text { policies, particularly on tobacco. } \\
\text { Although there was a smoking room in } \\
\text { the school, teachers were smoking in the } \\
\text { corridors and particularly in the school } \\
\text { yard. The intervention on the prohibition } \\
\text { of cigarette sales to minors by } \\
\text { convenience stores was not supported by } \\
\text { parents }\end{array}$ & $\begin{array}{l}\text { Recommendation respected for parents, } \\
\text { but not respected in terms of policy } \\
\text { reinforcement, for instance. Resistance } \\
\text { was clearly expressed by teachers in this } \\
\text { regard }\end{array}$ \\
\hline Cultural adaptation & $\begin{array}{l}\mathrm{NCl} \text { : Programme socially and culturally } \\
\text { acceptable to each community }\end{array}$ & $\begin{array}{l}\text { The intervention was designed and } \\
\text { tested to reach children in different } \\
\text { ethnic communities. Children, parents, } \\
\text { and representatives of the four largest } \\
\text { ethnic communities in the St-Louis du } \\
\text { Parc area were consulted on their habits. } \\
\text { This information was incorporated into } \\
\text { the curriculum. Then, the ethnic } \\
\text { components as we had understood them } \\
\text { were evaluated by children, teachers, } \\
\text { content committees and an advisory } \\
\text { committee. Note that at this stage, our } \\
\text { position on using children as an agent } \\
\text { for change within the family had been } \\
\text { challenged and had to be rejected }\end{array}$ & $\begin{array}{l}\text { Recommendation respected. The } \\
\text { implementation assessment of the school } \\
\text { based curriculum indicated that the } \\
\text { teachers sometimes had difficulty } \\
\text { incorporating attitudes or activities } \\
\text { related to ethnic dimensions }\end{array}$ \\
\hline
\end{tabular}

data at one year were $71.6 \%$ in intervention and $60.5 \%$ in comparison schools. They were $74.0 \%$ and $57.9 \%$ respectively in comparison schools in the two year follow up. ${ }^{20}$

Smoking status was measured in two items adapted from previous research. ${ }^{31}$ Students were categorised as neversmokers if they reported no smoking at all during their lifetime. Ever-smokers included subjects who reported any smoking during their lifetime, even just a puff. Current smokers included subjects who reported smoking one or more times in the past year.

An implementation evaluation was conducted through surveys of fourth, fifth, and sixth grade teachers in the experimental schools, at three time points during the project. This evaluation assessed the role of organisational factors, personal characteristics (such as smoking status), and implementation strategies on the implementation of the programme. ${ }^{25}$

In order to assess the relation between intensity of exposure to the programme and the strength of the reverse effects on smoking, each school was categorised according to the intensity of the programme actually delivered, based on implementation evaluation and administrative information about: the number of smoking curriculum hours given; the amount of time the health educator was present in the school; the number of interventions conducted targeting parents and teachers; and the extent of local community groups' collaboration. Low intensity schools included those with less than three hours of the smoking curriculum annually and no more than one smoking prevention activity outside the classroom.

\section{RESULTS}

Detailed descriptions of the study methods and the main results have been reported elsewhere. ${ }^{20}$ For this paper, we stratified schools by intensity of programme delivery to examine if the relation between exposure and outcome differed according to intensity. 
Compared to low intensity schools, the reverse impact of the programme was more pronounced in high intensity schools (table 1). In low intensity schools, the programme had no effect on smoking initiation (tendency for never-smokers to become ever-smokers). However, the St-Louis du Parc Heart Health Project increased both smoking initiation and maintenance (tendency for current smokers to retain that status) in high intensity schools, as well as maintenance in low intensity schools.

In order to identify deficiencies in programme design that might explain the reverse effects, all programme components were submitted to a critical appraisal using three sets of current guidelines for the design and implementation of school based smoking prevention programmes: those of the National Cancer Institute, ${ }^{27}{ }^{32}$ of the Institute of Medicine, ${ }^{21}$ and the Centers for Disease Control and Prevention, ${ }^{33}{ }^{34}$ as well as those identified in a literature review $247810162635-53$ (table 2). According to this analysis, the St-Louis du Parc Heart Health Project was consistent with several key guidelines: it used a comprehensive approach; it was culturally adapted; it used relevant content and methods of integrating the content; it had recommended intensity levels; it included booster sessions; it was appropriately timed with respect to students' ages and grades; it used teachers as well as health professionals to deliver interventions; and it included teacher training. However, two criteria were only partially respected. First, sustained activity to strengthen school smoking policies was not undertaken because of overwhelming resistance from teachers. Second, support for smoking cessation efforts (by students) and teachers was provided on an ad-hoc individual basis, rather than through systematic cessation programmes.

\section{DISCUSSION}

The St-Louis du Parc Heart Health Project conformed to most recommendations for effective prevention of tobacco consumption among primary school children, yet had the opposite effect. Consultation and reflection among tobacco experts resulted in several possible explanations for the reverse effects. In the following section we first discuss the importance of the social (parents, instructors, siblings) and physical (smoke-free area bylaws, law forbidding the sale of tobacco products to minors) environments on smoking initiation. Next, we discuss the number and quality of anti-smoking interventions in schools, including the presence of health educators, frequency of anti-tobacco messages, adaptation of messages to the developmental stages of children, and finally the cultural adaptation of anti-smoking activities.

\section{Physical and social environment}

Comprehensive school based tobacco prevention programmes such as the St-Louis du Parc Heart Health Project generally intend to operationalise a socio-ecological paradigm, on the premise that children's behaviour is strongly influenced by their physical and social environments. This perspective holds that effective school based smoking prevention must take into consideration the prevailing smoking norms and policies, siblings, parents' and teachers' attitudes and behaviour, participants' socio-demographic characteristics, and tobacco industry tactics, in interventions that are targeted to specific participants and reinforced by multi-component tobacco prevention and control efforts. ${ }^{29} 54$

Several environmental components of the St-Louis du Parc Heart Health Project were not implemented as planned. For example, systematic enforcement of tobacco control policies in experimental schools was not undertaken because of negative reactions by parents $s^{55}$ and teaching staff, so that teachers continued to smoke on school premises during the entire five year programme. The sociophysical environment in experimental schools was therefore inconsistent with the anti-smoking messages delivered through the curriculum. In addition, interventions aimed at stopping the sale of single cigarettes to minors in local conveniences stores were not supported by all of the schools' parent committees, ${ }^{55}$ contributing to continued easy access to tobacco products. These factors may have worked at cross purposes with the in-class intervention. In a study of 32 Quebec communities, Frohlich ${ }^{565}$ showed that primary school students' smoking initiation is associated with characteristics of their social environment and local resources for tobacco restrictions, so that the more prevalent smoking is among high status children and the more ambiguous the rules and laws in the community, the more children will be sensitised to the inconsistency and turn toward smoking. Recent results from the US state of Oregon, ${ }^{58}$ Wales, ${ }^{59}$ and Spain $^{60}$ suggest an association between school policy strength, policy enforcement, and smoking behaviours of high school students-prevalence of smoking is lower in schools where student smoking restrictions are enforced.

Our consultations carried out with tobacco experts reinforced the importance of interventions driven by a comprehensive ecological model. However, it was suggested that for environmental interventions to be effective, they should be on a larger scale than that afforded by a neighbourhood level intervention, probably under provincial (state, district) leadership to ensure better coordination of actions. Community and other non-governmental organisations should be encouraged to play a major role in local anti-smoking interventions. ${ }^{23}$ For example, although the law forbidding the sale of tobacco products to minors is part of a provincial action plan, its application is local in that every neighbourhood is responsible for implementation in convenience stores in its territory. In our case, the law had not been implemented provincially, which led to its inconsistent application locally. Moreover the experts also emphasised that more understanding is needed of how the interactions among the various social and physical environmental factors influence children's smoking behaviour, especially among younger children.

\section{Differential reverse effects}

We sought explanations as to why the strongest reverse effects on smoking were observed in the four St-Louis du Parc schools where programme intensity was greatest. While involved in all eight experimental schools, the health educator was much more intensively involved in the four schools that showed the greatest negative impacts. Our implementation evaluation indicated that several teachers in these four schools preferred that the smoking content of the curriculum be delivered by the health educator. It is possible that the reverse effects were attributable, at least in part, to the educator. He could have been perceived to be pro-smoking by the children or he could inadvertently have passed pro-smoking messages. Our results evoke those of the Alert project, ${ }^{16}$ where schools in which the anti-smoking curriculum was delivered by an adult health educator in conjunction with teen leaders showed higher levels of continued smoking among baseline smokers in intervention compared to control schools.

The association between intervention intensity and increased smoking invites consideration of the effects of repeated anti-smoking messages on children in this age group. It could be that multiple messages about smoking from diverse sources piques children's curiosity, rendering them more aware of and sensitive to smoking, and more interested in experimentation. At the same time, if these sensitised children are exposed to smoking cues and models in their social environment, they could become acutely aware of the contradiction between their environments (for example, visibly smoking teachers and parents, easy access to cigarettes) and anti-smoking in-class messages, and more motivated to resolve the contradiction (cognitive dissonance) in favour of the most normative solution-that is, by becoming more favourable to smoking. 
Health education programmes delivered in school settings must take the readiness of children for certain types of information into consideration. Primary school children try to make sense of educational information by transposing it to their daily experiences. When the information provided contradicts their experience, or when it suggests dangers to their parents' health, ${ }^{61}$ the resulting dissonance can create anxiety. Adaptive defence mechanisms such as denial, negation or rejection could block information integration, and render the programme ineffective. However, if the anxiety defence mechanisms result in transformation of the messages into their opposite in order to resolve the dissonance, the risk of reverse effects would be increased. A mechanism of this type may be responsible for the increased smoking initiation observed in non-smoking children in St-Louis du Parc Heart Health Project, and is consistent with our finding that smoking initiation risk is highest among children whose parents and siblings smoke, ${ }^{62}$ because these children would have the strongest need to resolve the dissonance.

One of the difficulties encountered when designing the programme in the early 1990s was the paucity of data on the effectiveness of programmes designed specifically for children aged 9-10 years. According to Piagetian stages of cognitive development and Kohlberg's stages of moral judgement, fourth grade children (ages 9 and 10 years) are likely to reason quite differently from sixth grade children (ages 12 and 13 years) ${ }^{63}$ These differences have implications for the design of anti-smoking interventions. In Piagetian terms, fourth grade children are generally in the concrete operations phase, where their reasoning is based on the organisation of concrete, tangible elements. At this stage, anti-smoking messages may be understood as simple instructions or orders not to smoke. In terms of moral reasoning, children at this age act to obey the wishes, as they perceive them, of significant adults. Messages from adults are taken very literally, with little possibility of conditionality. In the fifth and sixth grade, children are in transition toward the formal operations stage, and are able to begin imagining their reactions to hypothetical situations, such as someone offering them a cigarette, and to integrate abstract concepts such as the negative effects of smoking. Children in the formal operations stage are able to see both the good and bad sides of a behaviour, and develop a personal position in relation to abstract arguments.

The content of the St-Louis du Parc Heart Health Project was evaluated by a developmental psychologist and found to be appropriately designed in term of Piagetian and moral reasoning stages for grade 6 children, but less so for grade 4 children. The grade 4 curriculum focused on the effects of tobacco on the body and the environment, on myths about smoking, and on self assertion. In grade 4, the effects of tobacco on the body in terms of the abstract concept of "health" may have been too intangible for children to understand them. Similarly, 9 year olds may not have been able to fully benefit from the self assertion content if they were not able to comprehend the hypothetical situations proposed in the curriculum. This may have caused the younger children to focus most directly on the concrete topic of smoking, increasing their awareness and interest in it without adequately communicating the prevention messages. Indeed, analyses of the outcome data showed that the reverse effects on smoking initiation were especially strong, relative to controls, among grade 4 intervention children. ${ }^{20}$

Few similar projects have targeted disadvantaged youth in multiethnic environments, ${ }^{21}$ and little is known about appropriate cultural adaptation of the content and method of delivery of smoking prevention programmes in these settings. The St-Louis du Parc Heart Health Project was developed to reach children with diverse family origins. To ensure cultural adaptation, the programme messages were pre-tested in several cultural groups and modified based on the results. ${ }^{23}$ The teachers' curriculum materials identified issues and strategies for communicating health messages to specific cultural groups, and all teachers attended a training session on multiculturalism offered by their school board. Nevertheless, it is possible that despite the precautions taken to adapt the programme content appropriately, inadequate adaptation led students to misinterpret the anti-smoking messages. It is also possible that children newly arrived to Canada are more vulnerable to smoking during an acculturation period; they may see smoking as normative and a route to becoming integrated into the dominant culture. The programme may have inadvertently encouraged smoking during this vulnerable period. The likelihood that this occurred may vary according to specific cultures and recency of immigration. Although ethnic composition of the samples was controlled in the study design and analyses, the intervention group included children of more recent immigrants and of somewhat different ethnic origins from children in the comparison group. ${ }^{20}$ In addition, the ethnic mix of students evolved over the study period in both the intervention and comparison schools. It may be that the reverse effects are associated with ethnicity variables not measured or controlled in the study.

In summary, two hypotheses were retained: (1) the physical and social environments to which subjects were exposed provided mixed messages so that there was no clear non-smoking norm; (2) the intervention may have encouraged tobacco use because of its novelty, intensity, content, or (lack of adequate) cultural adaptation. Alternatively the dynamic personality of the health educator may have encouraged children to smoke.

\section{Standard guidelines: need for greater precision}

Three groups of US experts published guidelines on the school based prevention of tobacco use by youth. First, in 1987 the National Cancer Institute brought a panel of experts together and this group published guidelines in $1989 .{ }^{32}$ In $1991,{ }^{27}$ the components required for a school based programme were published. Then, in 1994, while endorsing these directives, the Centers for Disease Control ${ }^{33}$ added elements concerning policies, parental involvement, and support for students wishing to quit smoking. The Institute of Medicine's committee ${ }^{21}$ on the prevention of nicotine use in children and youth stressed the importance of national leadership, a comprehensive approach, and consistent research. Finally, the Centers for Disease Control re-endorsed in $1999^{34}$ the same recommendations as those published in 1994, stressing the importance of incorporating anti-tobacco programmes into a comprehensive school based programme, as well as the importance of combining school based efforts with community coalitions and national anti-tobacco campaigns.

Comparison of the St-Louis du Parc Heart Health Project to standard guidelines (table 2 ) $^{2127334}$ raised questions about several statements in these guidelines and their implications. Although they provide helpful overall design orientations, much is left to interpretation when programmes are actually operationalised. For example, the specific elements of effective parental involvement in smoking prevention are not defined. In addition, directives for achieving cultural adaptation are also not explicit. However, although we call for greater precision in these guidelines to facilitate operationalisation, it is clear that much more work is needed to develop the "evidence base" to achieve this precision.

\section{Conclusion}

Comprehensive school based smoking prevention programmes are a key strategy to reach children with important health messages. However, our experience with unanticipated reverse effects related to exposure to a state-of-the-art smoking prevention programme necessitates stepping back and carefully reviewing the paradigms underlying these programmes. We suggest that existing norms and consensus guidelines formulated in the early 1990s need to be revisited 


\section{What this paper adds}

Young people start smoking very early. Many comprehensive, school based programmes were implemented in different environments to counter this phenomenon. But, for the last few years, results have indicated that these programmes have had mitigated success: short term effect, no effect, and, for some, a negative effect.

and questioned, to help identify the directions for school based interventions in the years to come. The critical appraisal undertaken with respect to the St-Louis du Parc Heart Health Project aims to broaden the debate on avenues of action targeting primary school children, so that future interventions and research can make a more effective contribution to eliminating smoking initiation and improving children's health outcomes.

The results of this appraisal strongly suggest that school based interventions should begin by developing a clear and coherent social norm on the non-use of tobacco. Before implementing interventions aimed directly at children, school programmes should ensure that non-smoking legislation is implemented and enforced and that proximal environments (commercial and public spaces, business practices) are also operating in coherence with a non-use norm. Prevention programmes should systematically include cessation support for significant adults, most notably parents and teachers. Only then should direct within-school intervention be provided for children. The programme design should take key student characteristics into consideration, including sex, lifestyle, socioeconomic status, and ethnicity. It should also target children's stages of cognitive and moral development appropriately.

This leads us to endorse the recommendations of the California Department of Health Services, ${ }^{64}$ that prevention programmes "should not concentrate on youth as a primary target group. The goal is to build a social environment where families do not use tobacco, and adults are positive role models for youth" (page 20). According to these recommendations, school based tobacco prevention and education programmes should be established "only if certain stringent conditions are met: 1 - only if a vigorous community-wide program addressing broad social norm change is also supported" (school-based programmes should coordinate with other local tobacco control activities and programmes in the community); "2only if the programs consist of well-developed, sustainable interventions that reach kids at the school site and in classrooms; and 3-only if accountability mechanisms are built in to insure that the programs have school-site and teacher buy-in, and include intensive technical assistance and training for teachers" (page 20). We note, however, that recommendation would have precluded inclusion of our intervention and comparison schools from the St-Louis du Parc Heart Health Project.

Moreover, neighbourhood level interventions should be orchestrated to complement regional, provincial, and national programmes. In our case, a stronger provincial leadership on tobacco issues through policy and legislation would have enhanced coordination of actions, especially those directed to the creation of smoke-free environments and the limitation of access to tobacco products to children. Finally, school based health promotion programmes should be integrated into a broader, long term education policy, ${ }^{65}$ as education is a strong predictor of healthy choices about tobacco.

\section{ACKNOWLEDGEMENTS}

This research was conducted as part of the Projet québécois de démonstration en santé de coeur, which was funded by the National
Health Research and Development Program, Health Canada (grant 66053754-H), the Quebec Heart and Stroke Foundation, and the Quebec Ministry of Health and Social Services. Lise Renaud was a senior scholar of the Conseil québécois de la recherche sociale during the time this research was conducted. Jennifer O'Loughlin was a National Health Research Scholar during the time this research was conducted, and is currently a Canadian Institutes of Health Research Investigator. The authors thank: Roy Cameron, University of Waterloo; Penny Detscher and Ursula Bauer, Tobacco Youth Program, Florida; John Elder, University of California; Roberta Ferrence, Ontario Tobacco Research Unit; Brian Flynn, University of Vermont; Thomas Glynn, American Cancer Society; Lawrence Green, Centers for Disease Control; Cheryl Moyer, Canadian Cancer Society; John Pierce, University of California, and the members of the internal review committee: Nicole Beaudet, Monique Caron-Bouchard, Eric Goyer, Francine Hubert, Natalie Kishchuk, Nicole Perreault and Jean-Pierre Roy.

\section{Authors' affiliations}

L Renaud, J O'Loughlin, V Déry, Public Health Department, Montreal Centre/Université de Montréal/UQAM, Montreal, Quebec, Canada

\section{REFERENCES}

1 Elder J, Perry C, Stone E, et al. Tobacco use measurement, prediction and intervention in elementary schools in four states: the CATCH study. Prev Med 1996:25:486-94.

2 Schaps E, Moskowitz J, Malvin J, et al. Evaluation of seven school-based prevention programs: a final report on the NAPA project. Int J Addictions 1986;21:1081-112.

3 Perry CL, Kelder SH, Murray DM, et al. Community wide smoking prevention: long-term outcomes of Minnesota heart health program. Am J Public Health 1992:82:1210-6.

4 Resnicow K, Robinson T. School-based cardiovascular disease prevention studies: review and synthesis. Ann Epidemiol 1997;S7:S1 4-31

5 O'Connor SC, Cohen JE, Osterlund K. Comprehensive tobacco control programs: a review and synthesis of evaluation strategies in the United States, Ontario Tobacco Research Unit, Special Report, Toronto, June 2001.

6 Ellickson P, Bell R, Mcguigan K. Preventing adolescent drug use: long-term results of a junior high program. Am J Public Health 1993:83:856-61.

7 Donaldson S, Sussamn S, Mackinnon D. Drug abuse prevention programming: do we know what content works? Am Behav Sci 1996;39:868-83.

8 Chou C, Montgomery S, Pentz M, et al. Effects of a community-based prevention program on decreasing drug use in high-risk adolescents. Am J Public Health 1988;6:944-8.

9 Peterson A, Kealy K, Mann S, et al. Hutchison smoking prevention project: long term randomized trial in school-based tobacco use prevention-results on smoking, J Natl Cancer Inst 2000;92:1979-91.

10 Price J, Beach C, Everett S, et al. Evaluation of a three year urban elementary school tobacco prevention program. J School Health 1998;68:26-31

11 Coté F. La promotion en milieu scolaire du maintien se l'abstinence tabagique au sein d'une cohorte d'enfants de 10-12 ans, Doctoral thesis, Université De Montréal, 2002.

12 Botvin GJ, Sussman S, Biglan A. The Hutchinson smoking prevention project: a lesson on inaccurate media coverage and the importance of prevention advocacy. Prevention Science 2001;2:67-70.

13 Hawthorne $\mathbf{G}$. The social impact of life education: estimating drug use prevalence among Victorian primary school students and the statewide effect of the life education programme. Addiction 1996;91:1151-9.

14 Wallace S. A critique of Hawthorne et al's evaluation of life education. Addiction 1996;91:286-91.

15 Wheller R. Evaluating the evaluators: a reply to Hawthorne et al. Addiction 1995:90:293-4.

16 Ellickson P, Bell R. Drug prevention in junior high school: a multi-site longitudinal test. Science 1990;247:1299-305.

17 Gilchrist L, Schinke S, Bobo J, et al. Self-control skills for preventing smoking. Addict Behav 1986;11:169-74.

18 Nutbeam D, Macaskill P, Smith C, et al. Evaluation of two smoking education programmes under normal classroom conditions. BM 1993;306:102-7

19 Renaud L, Dery V. Critical thinking on smoking prevention in the elementary school setting. Direction de la santé publique de Montréal-Centre, Canada, 2000

20 O'Loughlin J, Renaud L, Paradis G. Impact of a heart health promotion program for schoolchildren in low income, multi-ethnic neighborhoods. Direction de la santé publique de Montréal-Centre, Canada, 1999.

21 Institute of Medicine. Growing up tobacco free. Washington DC: National Academy Press, 1994.

22 Renaud L. Réflexions critiques au sujet d'un modèle conceptue transposé dans le design d'un programme communautaire et multifactoriel en promotion de la santé auprès d'enfants. In Bastien $R$, Langevin L, Laroque G, Renaud L. Promouvoir la santé. Montréal: Collection Partage, REFIPS, 1994:213-28. 
23 Renaud, L, Dufour, R, O'Loughlin J. Intervenir localement selon les cinq axes de la charte d'Ottawa: défi de la promotion. Ruptures 1997;4:23-34

24 Renaud L, O'Loughlin J, Paradis G, et al. Un programme de promotion de la santé cardiovasculaire auprès des 9 à 12 ans et de la communauté St-Louis du Parc/Québec. Santé publique 1998;10:425-45.

25 Renaud L, Chevalier S. L'évaluation de l'implantation d'un curriculum scolaire: pistes d'interventions pour optimiser l'adoption et l'implantation de programmes d'éducation à la santé dans les écoles primaires. Can J Public Health 1997:88:351-4.

26 Rundall T, Bruvold W. A meta-analysis of school-based smoking and alcohol use prevention programs. Health Education Quarterly 1988, 15:317-34.

27 Glynn TJ, Anderson DM, Schwarz L. Tobacco-use reduction among high-risk youth: recommendations of a National Cancer Institute expert advisory panel. Prev Med 1991;20:279-91.

28 Santi S, Best J, Payne M, et al. A comparison between instructional experience of teachers and nurses delivering a smoking prevention program. Can J Public Health 1992;83:433-6.

29 Lantz $\mathbf{P}$, Jacobson $\mathrm{P}$, Warner $\mathrm{K}$, et al. Investing in youth tobacco control: a review of smoking prevention and control strategies. Tobacco Control 2000;9:47-63

30 Smith DW, McCormick L, Steckler A, et al. Teacher's use of health curricula: implementation of growing healthy project smart and the teenage health teaching module. I School Health 1993:63:349-54.

31 Flynn B, Worden J, Secker-Walker R. Prevention of cigarette smoking through mass media intervention and school programs. Am J Public Health 1992;82:827-33

32 Glynn T. Essential elements of school-based smoking-prevention programs. J School Health 1989:59:181-8.

33 US Department of Health and Human Services. Guidelines for school health programs to prevent tobacco use and addiction. MMWR Morb Mortal Wkly Rep 1994;43:1-18.

34 Centers for Disease Control. Best practices for comprehensive tobacco control programs - August 1999. Atlanta Georgia: US Department of Health and Human Services, Centers for Disease Control and Prevention, National Center for Chronic Disease Prevention and Health Promotion, Office on Smoking and Health. URL: http://www.cdc.gov/tobacco.

35 Botvin G, Baker E, Filazzola A, et al. A cognitive behavioral approach to substance prevention: one-year follow-up. Addict Behav 1990; 15:47-63

36 Perry C, Telch M, Killen J, et al. High school smoking prevention: the relative efficacy of varied treatments and instructors. Adolescence 1993;28:561-6.

37 Botvin G, Baker E, Dusenbury L, et al. Long-term follow-up results of a randomized drug abuse prevention trial in a white middle-class population. JAMA 1995;273:1 106-12.

38 Donnelly J, Jacobsen D, Whately J. Nutrition and physical activity program to attenuate obesity and promote physical and metabolic fitness in elementary school children. Obesity Research 1996:4:229-43.

39 Killen J, Telch M, Robinson T, et al. Cardiovascular disease reduction for tenth graders. A multiple-factor school-based approach. JAMA 1998;260: 1728-33

40 Walter H, Vaughn R, Wynder E. Primary prevention of cancer among children: changes in cigarette smoking and diet after six years of intervention. J Ntl Cancer Inst 1989;81:995-9.

41 Bush P, Zuckerman A, Theirss P, et al. Cardiovascular risk factor prevention in black schoolchildren: two-year results of the Know Your Body Program. Am J Epidemiol 1989;129:466-82.

42 Vandongen $\mathbf{R}$, Jenner $D$, Thompson $C$, et al. A controlled evaluation of a fitness and nutrition program on cardiovascular health in 10 to 12 year old children. Prev Med 1995;241:9-22.
43 Puska P, Vatiainen E, Pallonen U, et al. The North Karelia Youth Project: Evaluation of two years of intervention on health behaviour and CVD risk factors among 13 to 15 year old children. Prev Med 1982;11:550-70.

44 Tell G, Vellar O. Noncommunicable disease risk factor intervention in Norwegian adolescents: the Oslo youth study. In: Hertzl B, Berenson G, eds. Cardiovascular risk factors in childhood: epidemiology and prevention. Amsterdam: Elsevier Science, 1987.

45 Dusenbury L, Falco M, Lake A. A review of the evaluation of 47 drug abuse prevention curricula nationally available. J School Health 1997;67:127-32

46 Dusenbury L, Falco M. Eleven components of effective drug abuse prevention curricula. J School Health 1995;65:420-5.

47 Bruvold W. A meta-analysis of the California school-based risk reduction program. J Drug Education 1990;20:139-52.

48 Ambtman R. Evaluation of a comprehensive elementary school curriculum-based drug education program. J Drug Education 1990;20: 199-225.

49 Dent C, Sussman S, Stacy A, et al. Two-year behavioral outcomes of Project Toward No Tobacco Use. J Consult Clin Psychol 1995:63:676-7.

50 Worden J, Flynn B, Solomon L, et al. Using mass media to prevent cigarette smoking among adolescent girls. Health Education Quarterly 1996;23:453-68

51 Secker-Walker R, Worden J, Holland R, et al. A mass media programme to prevent smoking among adolescents: costs and cost-effectiveness. Tobacco Control 1997:6:207-12.

52 Hamm N. Outcomes of the Minnesota smoking prevention program. Psychological Reports 1994;75:880-2.

53 Cohen D, Linton K. Parent participation in an adolescent drug abuse prevention program. J Drug Education 1995;25:159-69.

54 Ontario Tobacco Research Unit. School-based tobacco use prevention programs: should they be abandoned? Research Update March 2002.

55 Damestoy N, Renaud L, et al. L'interdiction de la vente de cigarettes aux mineurs: une concertation est nécessaire. Can J Public Health 1994; 85:85-8

56 Frohlich KL, Potvin L, Chabot P, Corin E. A theoretical and empirical analysis of context: neighbourhoods, smoking and youth. Soc Sci Med 2002:54:1401-17

57 Frohlich KL, Potvin L, Gauvin L, et al. Youth smoking initiation. Disentangling context from composition. Health and Place 2002,$8 ; 155-66$.

58 Centers For Disease Control and Prevention. Effectiveness of school-based programs as a component of a statewide tobacco control initiative - Oregon 1999-2000. MMWR Morb Mortal Wkly Rep 2001;50:663-6.

59 Moore L, Roberts C, Tudor-Smith C. School smoking policies and smoking prevalence among adolescents: multilevel analysis of cross-sectional data from Wales. Tobacco Control 2001;10:117-23.

60 Pinilla J, Gonzalez B, Barber P, et al. Smoking in young adolescents: an approach with multilevel discrete choice models. J Epidemiol Community Health 2002;56:227-32.

61 Brown J, Kreft L. Zero effects of drug prevention programs: issues and solutions. Evaluation Review 1998;22:3-14.

62 O'Loughlin J, Paradis G, Renaud L, et al. One-year predictors of smoking initiation and of continued smoking among elementary schoolchildren in multiethnic, low-income, inner-city neighborhoods. Tobacco Control 1998;7:268-75.

63 Berk L. Child development. Boston: Allyn and Bacon, 1989.

64 California Department Of Health Services. A model for change: the California experience in tobacco control. California: Department of Health, 1998.

65 Marmot $M$. The social pattern of health and disease. In: Blane D, Brunner E, Wilkinson R, eds. Health and social organization. London: Routledge, 1999 